\title{
Premium Evaluation in Mergers and Acquisitions of Electricity Companies
}

\author{
Aleksandr Sterkhov \\ Master of Economics \\ Senior Lecturer \\ $\underline{\text { ORCID }}$ \\ E-mail: trader-st@mail.ru
}

Graduate School of Economics and Management, Ural Federal University, Ekaterinburg, Russia

Journal of Corporate Finance Research, Vol. 13, No. 3, pp. 48-60 (2019)

DOI: https://doi.org/10.17323/j.jcfr.2073-0438.13.3.2019.48-60

Received 23 April 2019 | Peer-reviewed 15 June 2019 | Accepted 3 September 2019 


\section{Premium Evaluation in Mergers and Acquisitions of Electricity Companies}

\section{Abstract}

The purpose of this research is to build a model for estimating the relative premium in mergers and acquisitions involving electric power companies. This evaluation is based on four groups of factors: the company's operating and financial results, the country in which the company operates, the industry the company belongs to, and the debt market conjuncture.

This paper is based on a comparative business valuation method. The empirical base of this research includes data on 6504 deals that have occurred throughout the world from 1997 to 2018 . This data is sourced from the Zephyr database (https://www.bvdinfo.com), which includes data on both public and non-public companies for which the amount paid in a deal is known, as well as the value of total assets.

The results of this research demonstrates that this categorisation of industries, (achieved via a mathematical algorithm) corresponds almost identically to the existing industry structure of the electric power industry. The coefficient of determination of the final econometric model is more than 20 percent, which indicates a high-quality assessment. This is because the relative premium is predicted (and not the amount paid in the deal), which is in close correlation with the value of the company's assets.

The scientific novelty of this paper consists in our clarifying of the conceptual apparatus (the relative premium term introduced in a deal), the selection and grouping of factors which affect the size of the relative premium, and the identification and quantifying of the influence of variables included in each group of factors. This article proposes the author's approach to the categorisation of countries and industries based on the equality of premium coefficients in the regression, as well as categorisation by groups of countries and industries with equal premiums.

This composition outlines a methodology that may be used to predict the value of a business, as well as determining the value paid in a deal, in cases where such information is not available publicly. This will be of obvious interest to anyone involved in business or research in several fields. Further, as concerns further development of these results, various interesting features are highlighted which are beyond the scope of this research to investigate further. For example, the relative premium seems to be determined by variables related to the quality of the institutional environment. The correlation of political stability and premium value arises, providing fresh ground for future study.

Keywords: corporate finance, financial ratios, value of firm, acquisition, buyout, merger, takeover, target firm JEL classification:G30, G34 


\section{Introduction}

This article analyses the factors that determine the amount of relative premium in mergers and acquisitions (M\&As). The choice of the electric power industry is due to the fact that a significant amount of deals in this industry take place within the territory of the Russian Federation. In addition, the electric power industry is one of the basic industries of any economic system, on the development of which the dynamics of the remaining industries and services depend.

The purpose of this research is to build a model for estimating the relative premium in mergers and acquisitions of companies in the energy sector, using the comparative business valuation method.

The main hypothesis of the research is as follows: the parameters of the model for estimating the relative premium in mergers and acquisitions depend on four groups of factors: the operating and financial activities of the company, the market conditions, the industry sector of the company, and the country the company operates in or is based in.

The following results will be presented: the concept of relative premium is formulated, and a clustering of countries and industries is constructed according to the criterion of equality of relative premium in the field of electricity.

The novelty of this research approach is highlighted by the following observations, which will be explicated in the body of this article:

1) A classification of factors influencing the size of the relative premium in mergers and acquisitions deals is articulated.

2) The companies analysed are active in and related to the electric power industry. Companies in this industry have a wide range of assets, which is consistent with the objectives of the present study. Besides this, sectoral-specific risk factors and commercial motivations are more coherent and aligned than when analysing the entire market for mergers and acquisitions.

3) This analysis consists of both public and non-public companies.

4) The premium in an M\&A deal is defined as the difference between the amount paid in the deal, adjusted for the acquired stake of the company, and the modelled value of the company in accordance with the size of the assets.

5) As an explanatory variable, the relative premium is identified as the quotient attained by dividing the premium in the deal by the modelled value of the company in this study. This approach allows us to unify the companies whose assets differ significantly.

\section{Literature review and hypotheses}

Considering the literature on mergers and acquisitions, it should be noted that most studies are very different from the methodology adopted in this work. First, in many studies, the dependent variable is CAR (cumulative abnormal return), which limits the analysis to public companies only. It is more informative for investors not to study the short-term reaction of the market to the appearance of information about a deal or to conclude a deal, but to analyse the premium based on the amount that was actually paid. In addition, many dependent papers use other dependent variables based on survey data. Secondly, the main goal of this work is to understand exactly what factors the country and industry premiums depend on. Understanding this will make it possible in the future for researchers or business practitioners to correctly apply the patterns obtained in other countries or other industries.

The research work cited at [7] addresses the issue of the dependence of the premium in the deal and the length of the deal's processing period. The authors concluded that increasing the time interval between the moment of hearing of the deal and the moment of announcement of the deal means an increase in premium. At the same time, the research methodology in [7] uses the CAR principle, so we would like to check these findings with respect to the relative premium.

Industry characteristics of mergers and acquisitions of Russian companies are analysed in the research work cited at [3]. The authors used the logic of distinguishing individual industries and using cross variables, which are products of industries and other variables. We use a similar methodology to assess the impact of individual industries on the parameters of mergers and acquisitions.

It is worth noting that the research methodology in the work cited at [1] cannot be fully comparable with the present study, since it is not the premium in the deal that is evaluated, but an integral assessment of the success of the deal.

The following papers provide an assessment of cultural factors affecting premiums in mergers and acquisitions. In particular, K.R. Ahern [8] draws attention to the fact that the prize negatively depends on such characteristics of the national culture as trust, hierarchy, and individualism. Drawing analogies with the objectives of this study, we can assume that countries with similar cultural characteristics should have a comparable premium and fall into clusters with the same premium size.

The research methodology in the work cited at [9] is significantly different from the assumptions of this study: the probability of becoming the object or initiator of a merger or acquisition deal is estimated. In addition, the authors examine only cross-border mergers and acquisitions. The results of the study [9] demonstrate that the level of economic development of a country and the quality of accounting affect the behavior of firms in mergers and acquisitions. The Bauer andMatzler study [10] uses data on mergers and acquisitions of European companies, and uses similar indicators characterising the level of cultural proximity of countries. The level of political affinity of countries as a factor in mergers and acquisitions was used in a study by Bertrand, as a result of which it was conclud- 
ed that the political affinity of countries means a large premium in mergers and acquisitions. Applying the principle of analogy, it can be assumed that countries from groups with similar economic development may have a similar premium in mergers and acquisitions.

The importance of analysing macroeconomic factors also follows from the studies of A. Boateng et al. [11] and A. Bonaime et al. [12]. The authors of [11] conclude that macroeconomic factors are an essential variable that determines the behaviour of firms in mergers and acquisitions. The Bonaime study [12] emphasises that political factors determine the intensity of mergers and acquisitions in a particular country: a higher level of political instability means a lower intensity of mergers and acquisitions. We believe that the premium in mergers and acquisitions may also depend on the country of the deal.

Quite close factors are described in the Col and Errunza study [13]. The authors draw attention to the fact that political risks associated with the seizure of property are an essential factor determining the reaction to mergers and acquisitions. In our opinion, this hypothesis is interesting for development in the framework of evaluating premiums in mergers and acquisitions, since a high risk of property seizure should be reflected in the framework of the premium.

In a number of studies, the authors focus on the allocation of geographical factors. Y. Cai et al.[14] found that the behavior of firms located in industrial areas has significant differences. We believe that this indirectly confirms that countries with different levels of industrial development may have different premiums.

Among the studies devoted to the analysis of electric power companies, we note the work of J. Kishimoto et al. [5], which contains an analysis of mergers and acquisitions from the position of financial indicators of companies.

From Russian studies, we consider the work of A.I. Balashov and S.V. Podtsikina [15], which assesses the impact of financial parameters on the value of pharmaceutical companies in merger and acquisition deals. The authors have explored 114 mergers and acquisitions deals in the pharmaceutical industry, which had taken place from 2003 to 2014. Deals in the BRICS countries were highlighted. This research revealed that the value of the deal is affected by the volume of assets and net profit, as well as the acquired stake in the capital. In my research, dummy variables for countries were used, but countries belonging to the same region do not necessarily have an equal premium.

The research by D.S. Luzina and E.M. Rogova, cited at [16], is based on the income model of business valuation. In current research, the cost business valuation method was implemented for this indicator because forecasting of profits or dividends in the long term may have a significant error.

Summing up the analysis of political factors, we conclude that it is necessary to build a complete classification of countries from the point of view of equality of premiums in mergers and acquisitions, since different studies focus on various factors, many of which are difficult to combine in one classification. This approach, in our opinion, will contribute to the search for patterns that caused individual companies to fall into the same cluster.

Hereby we posit the hypotheses grounding the approach to this research:

Hypothesis 1. One of the factors of the relative premium in mergers and acquisitions is the total assets of the company;

Hypothesis 2. It is possible to distinguish clusters of countries characterised by the same country premium;

Hypothesis 3. It is possible to identify clusters of industries characterised by the same industry premium;

Hypothesis 4. The time interval between the rumors of a transaction, the announcement of the transaction, and the completion of the transaction, is a factor affecting the value of the relative premium;

Hypothesis 5. The situation in the debt market is a factor affecting the value of the relative premium;

\section{Methodology and data}

First, it should be noted that the modeled enterprise value was chosen, rather than the size of the equity capital. The amount paid in a deal taking into account the acquired company share (EV) most tightly depends on the modeled enterprise value $\left(\mathrm{EV}_{\mathrm{m}}\right)$, but not on the value of the company's total or net assets.

This is confirmed by regression equations, in which the independent variable is the amount paid in a deal, adjusted for the acquired company share. The dependents in the three regression equations were the size of the modeled value $\left(\mathrm{EV}_{\mathrm{m}}\right)$, which represents the company's total and net assets, respectively. The regressions were evaluated by the standard least squares method with a constant. In this case, the determination coefficient for the equation, in which the modeled enterprise value $\left(\mathrm{EV}_{\mathrm{m}}\right)$ was used, is $95.32 \%$. For the equation, in which the total company assets logarithm was used, the coefficient is $11.02 \%$.

To conduct a comparative analysis of company value, statistical data on the conducted merger and acquisition transactions are necessary. The data source is the Zephyr database [17].

The econometric models defined in this article are based on an analysis of 6504 deals concluded between February 26, 1997 and September 30, 2018. The database included companies with industry affiliation to the 'utilities' group according to NAICS2017 classification. Companies for which the deal volume, total revenue or EBIT were unknown for the time of the transaction were excluded from the database.

Table 1 provides a quantitative description of the variables included in the study. The sample included data on companies belonging to the sectors of electricity generation and transportation. 
Table 1. Descriptive statistics for variables included in investigation

\begin{tabular}{|c|c|c|c|c|c|c|c|}
\hline & ASSETS & REVENUE & EBIT & $\mathbf{E V}$ & EV_D & $\mathbf{E V} \mathbf{M}$ & EV_R \\
\hline Mean & 7230.315 & 1898.704 & 180.6105 & 4679.732 & -1761.39 & 6441.125 & -21.0111 \\
\hline Median & 451.5185 & 172.693 & 4.8265 & 344.7154 & -37.568 & 475.2053 & -18.105 \\
\hline Maximum & 198929 & 53108 & 7809 & 148000 & 14403.89 & 148247 & 98.88712 \\
\hline Minimum & 0.001 & -5.051 & -5045.49 & 0.001595 & -31903.2 & 0.00112 & -99.9954 \\
\hline Std. Dev. & 15837.97 & 6321.262 & 677.1942 & 10615.91 & 3966.859 & 13688.33 & 29.93022 \\
\hline Obs. & 6504 & 6504 & 6504 & 6504 & 6504 & 6504 & 6504 \\
\hline
\end{tabular}

A grouping of factors determining the amount of premium in mergers and acquisitions was carried out for building an econometric model in this research.

An analysis of the database showed that many deals contribute to the acquisition of less than $100 \%$ of a company. Therefore, for the purposes of the analysis, an enterprise value $(\mathrm{EV})$ variable was generated, which represents the amount paid in the deal, adjusted for the company's share acquired in this deal:

$$
\mathrm{EV}=\frac{\text { Deal value }}{\text { Acquired stake }}
$$

where Deal value - the amount paid in the deal;

Acquired stake - the share of the company acquired in the deal.

The analysis also uses the deal modelled enterprise value $\left(\mathrm{EV}_{\mathrm{m}}\right)$, equal to:

$\mathrm{EV}_{\mathrm{m}}=\mathrm{Equity}+\mathrm{Debt}_{\mathrm{LR}}+\mathrm{Debt}_{\mathrm{SR}}+\mathrm{Cash}$

where Debt $_{\mathrm{LR}}$ - long-term debt;

Debt $_{\mathrm{SR}}$ - short-term debt;

Cash - cash and cash equivalents.

The first three components of formula (2) represent the value of the company's assets. Cash and cash equivalents are deducted because when buying a company, the owner pays the value of the assets and receives a company that owns a certain amount of cash and cash equivalents, which is equivalent to the situation when the company would have been bought for the value of assets minus cash and cash equivalents.

My approach does not take into account the size of the company's intellectual capital as a separate variable (a systematisation of features of innovative companies deals' is given in the article written by I.V. Skvortsova and A.D. Krasovitsky [18]). I think that the intangible assets of power companies are properly reflected in the relevant balance sheet items, so it is not necessary to make a separate variable for these assets.

In addition, the variable $\mathrm{EV}_{\mathrm{d}}$ (premium in the deal) was generated, representing the difference between the enterprise value paid in the deal (corrected for $100 \%$ of the company) and the modelled enterprise value, determined in accordance with the logic of the cost method:

$$
\mathrm{EV}_{\mathrm{d}}=\mathrm{EV}-\mathrm{EV}_{\mathrm{m}} \text {. }
$$

A positive value of $\mathrm{EV}_{\mathrm{d}}(3)$ means that the company was acquired at a price higher than the value of its assets (with a premium to the value of assets). A negative value means the acquisition was at a price lower than the value of its assets (at a discount to the value of assets).

To provide for a correct analysis of the company premiums with different asset values, the relative premium was calculated (variable $\mathrm{EV}_{\mathrm{r}}$ ):

$$
\mathrm{EV}_{\mathrm{r}}=\frac{\mathrm{EV}_{\mathrm{d}}}{\mathrm{EV}_{\mathrm{m}}} \cdot 100
$$

Relative premium, or $\mathrm{EV}_{\mathrm{r}}$ (4) is a premium as a percentage of the modelled enterprise value. This variable was used as the dependent variable in the regression equations presented in this paper.

Herewith we present a hypothesis that the factors determining the size of the relative premium in mergers and acquisitions of electricity companies can be grouped in the following way:

1) Factors relating to the operating and financial activities of the target company;

2) Country of the target company;

3) The industry of the target company;

4) Market conditions;

\section{Models and results}

When analysing the first group of factors (model 1) (operating and financial activities of the target company), the following indicators were selected: the volume of the target company assets, the $\mathrm{EBIT} / \mathrm{EV}_{\mathrm{m}}$ ratio, and the sales $/ \mathrm{EV}_{\mathrm{m}}$ ratio.

A number of studies analyse the impact of financial indicators on the success of merger and acquisition deals. The most commonly used indicators are the size of the company [1-6], the profitability of the company, the profitability of the object of absorption $[1 ; 5 ; 6]$, and asset turnover [5]. At the same time, the data on the influence of the size of 
the company on the size of the bonus are contradictory: papers $[1 ; 3 ; 5]$ indicate a positive effect of the size of the company on the size of the premium, and in the studies $[2 ; 4 ; 6]$, a negative impact is noted. These findings predetermined particular attention to the variable reflecting the size of assets for the present study.

The logarithm of the total assets of the target company (variable assets_l) was used as a variable reflecting the size of the company's assets. The usage of the logarithm was proposed in studies [19-21], and allows for a comparison of companies whose assets differ significantly. In addition, the usage of logarithm is a way of grouping companies by assets. An alternative approach, instead of using the logarithm, is grouping companies according to the level of assets, which is used, for example, by M.V. Maslennikova and I.M. Partin [22].

As an indicator reflecting financial activities, it is proposed to use the $\mathrm{EBIT} / \mathrm{EV}_{\mathrm{m}}$ ratio:

$$
\frac{\mathrm{EBIT}}{\mathrm{EV}_{\mathrm{m}}} \text {. }
$$

This indicator was chosen by analogy to the EBITDA/ sales ratio, used in the research of D.Y.Aharon [19]. In this paper, I use EBIT instead of EBITDA, since this indicator, in my opinion, better reflects the cash flows available to the investor. In addition, modelled enterprise value is used instead of sales because it will make possible to assess the effectiveness of the investor's funds usage.

The ratio of the revenue to modelled enterprise value was used as an indicator reflecting the company's operating activities:

$$
\frac{\text { Revenue }}{\mathrm{EV}_{\mathrm{m}}} \text {. }
$$

This indicator was proposed by analogy to the growth rate of sales from the study cited at [19]. The inclusion of the growth rate of sales in the model may be less representative for electric power companies, since different segments of this market are characterised by different average sales growth rates. In addition, zero or negative sales trends are not always a negative factor.

To build econometric models, the data was cleared of extreme values. The enterprises with extreme values whose relative deviations $\mathrm{EV}_{\mathrm{r}}$ exceed $100 \%$ were excluded. It appears that the acquisition of a company for a price twice that of the modelled enterprise value may be explained by the buyer's interests, possibly related to other companies that are in its ownership, which cannot be reflected in the proposed research methodology.

Based on the factors belonging to the first group, a regression model 1 was constructed. The equation of model 1 is

$$
\begin{aligned}
& \mathrm{EVr}=\beta_{0}+\beta_{1} \ln (\mathrm{ASSETS})+ \\
& +\beta_{2}\left(\frac{\mathrm{EBIT}}{\mathrm{EVm}}\right)+\beta_{3}\left(\frac{\mathrm{REVENUE}}{\mathrm{EVm}}\right),(7)
\end{aligned}
$$

where ASSETS is the total assets of the enterprise; and $\beta_{\mathrm{i}}$ are the parameter estimates.

The regression parameters were estimated by the least squares method with White's robust estimates of standard

\begin{tabular}{|c|c|c|c|c|c|c|c|c|}
\hline \multirow{2}{*}{ Variable } & \multicolumn{2}{|c|}{ Model 1} & \multicolumn{2}{|c|}{ Model 2} & \multicolumn{2}{|c|}{ Model 3} & \multicolumn{2}{|c|}{ Model 4} \\
\hline & $\beta_{\mathrm{i}}$ & $\mathbf{p}_{\mathbf{i}}$ & $\beta_{i}$ & $\mathbf{p}_{\mathbf{i}}$ & $\beta_{\mathrm{i}}$ & $\mathbf{p}_{\mathbf{i}}$ & $\boldsymbol{\beta}_{\mathrm{i}}$ & $\mathbf{p}_{\mathrm{i}}$ \\
\hline ASSETS_L & -2.602 & 0.000 & -2.504 & 0.000 & -2.438 & 0.000 & -2.424 & 0.000 \\
\hline 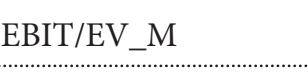 & 0.522 & 0.000 & 0.650 & 0.000 & 0.661 & 0.000 & 0.663 & 0.000 \\
\hline REVENUE/EV_M & 0.384 & 0.000 & 0.571 & 0.000 & 0.575 & 0.000 & 0.585 & 0.000 \\
\hline Group1 (Countries) & & & 56.265 & 0.000 & 55.554 & 0.000 & 55.769 & 0.000 \\
\hline Group2 (Countries) & & & -0.339 & 0.903 & 0.781 & 0.775 & 2.270 & 0.402 \\
\hline Group3 (Countries) & & & 78.986 & 0.000 & 79.845 & 0.000 & 79.661 & 0.000 \\
\hline Group4 (Countries) & & & 63.284 & 0.000 & 63.266 & 0.000 & 63.225 & 0.000 \\
\hline France & & & 72.454 & 0.000 & 70.684 & 0.000 & 67.794 & 0.000 \\
\hline Portugal & & & 42.117 & 0.000 & 44.136 & 0.000 & 44.283 & 0.000 \\
\hline Russia & & & 50.930 & 0.000 & 52.514 & 0.000 & 51.238 & 0.000 \\
\hline USA & & & 55.546 & 0.000 & 54.817 & 0.000 & 55.577 & 0.000 \\
\hline Group 1 (Industries) & & & & & -9.199 & 0.000 & -11.104 & 0.000 \\
\hline
\end{tabular}
deviations. The evaluation results are presented in Table 2 (model 1).

Table 2. Parameter estimates of models 1-4 


\begin{tabular}{|c|c|c|c|c|c|c|c|c|}
\hline \multirow{2}{*}{ Variable } & \multicolumn{2}{|c|}{ Model 1} & \multicolumn{2}{|c|}{ Model 2} & \multicolumn{2}{|c|}{ Model 3} & \multicolumn{2}{|c|}{ Model 4} \\
\hline & $\beta_{i}$ & $\mathbf{p}_{\mathbf{i}}$ & $\beta_{i}$ & $\mathbf{p}_{\mathbf{i}}$ & $\beta_{i}$ & $\mathbf{p}_{\mathrm{i}}$ & $\beta_{\mathrm{i}}$ & $\mathbf{p}_{\mathrm{i}}$ \\
\hline Group 2 (Industries) & & & & & -11.454 & 0.000 & -11.344 & 0.000 \\
\hline Group 3 (Industries) & & & & & -5.650 & 0.008 & -6.615 & 0.002 \\
\hline Group 4 (Industries) & & & & & 1.489 & 0.515 & 0.612 & 0.787 \\
\hline COMPL_ANN & & & & & & & -0.013 & 0.000 \\
\hline COMPL_RUM & & & & & & & 0.006 & 0.005 \\
\hline RUMR & & & & & & & 1.996 & 0.000 \\
\hline C & -5.820 & 0.000 & -66.948 & 0.000 & -60.963 & 0.000 & -61.722 & 0.000 \\
\hline R-squared & 0.084 & & 0.172 & & 0.187 & & 0.202 & \\
\hline F-statistic & 197.867 & & 123.031 & & 99.292 & & 91.179 & \\
\hline Prob(F-statistic) & 0.000 & & 0.000 & & 0.000 & & 0.000 & \\
\hline
\end{tabular}

Table 3. Groups of countries by the criteria of equality of relative premiums

\begin{tabular}{|c|c|}
\hline Group & List of countries \\
\hline $\begin{array}{l}\text { Group } 1 \\
\text { (Countries) }\end{array}$ & $\begin{array}{l}\text { United Arab Emirates, Austria, Australia, Bosnia and Herzegovina, Barbados, Bermuda, Bolivia, } \\
\text { Brazil, Canada, Switzerland, Chile, Colombia, Indonesia, Ireland, India, Iran, Iceland, Jamaica, } \\
\text { Japan, Kenya, Korea, Cayman Islands, Sri Lanka, Latvia, Morocco, Moldova, Montenegro, } \\
\text { Macedonia, Malta, Mexico, Malaysia, Nigeria, Slovakia, El Salvador, Thailand, Virgin Islands, Hong } \\
\text { Kong, Croatia, Italy, Luxembourg, Mauritius, Slovenia, Denmark, Estonia, Egypt, United Kingdom, } \\
\text { New Zealand }\end{array}$ \\
\hline $\begin{array}{l}\text { Group } 2 \\
\text { (Countries) }\end{array}$ & Oman, Zambia, Viet Nam \\
\hline $\begin{array}{l}\text { Group } 3 \\
\text { (Countries) }\end{array}$ & $\begin{array}{l}\text { Georgia, Hungary, Lithuania, Netherlands, Norway, Peru, Czech Republic, Finland, Poland, } \\
\text { Romania, South Africa }\end{array}$ \\
\hline $\begin{array}{l}\text { Group } 4 \\
\text { (Countries) }\end{array}$ & $\begin{array}{l}\text { Bangladesh, Belgium, Bulgaria, China, Germany, Greece, Philippines, Pakistan, Serbia, Sweden, } \\
\text { Turkey, Taiwan, Spain, Ukraine, Vietnam }\end{array}$ \\
\hline
\end{tabular}

Analysis of this model allows us to come to the following intermediate conclusions.

First, the adjusted determination of fit (the degree of linear correlation) for this model is about 8.4 percent. This indicator can be considered quite high, but of course this requires additional improvement. All coefficients of this regression are significant.

A negative coefficient of a logarithm of assets indicates that companies with a larger asset size have lower relative premiums in deals. This coefficient can be explained by the fact that large companies are subject to strict regulation by the state. In addition, the demand for such companies is lower due to the larger amount of money required for the deal.

The coefficients of EBIT/EV $\mathrm{m}_{\mathrm{m}}$ and Revenue/ $\mathrm{EV}_{\mathrm{m}}$ ratios are positive, which is expected. These ratios confirm that the higher the efficiency of asset usage and the higher the company's sales (which is also an indicator indirectly indicat- ing the quality of asset utilisation), the higher the relative premium that vendors are willing to pay in the deal.

Model 2 includes the second group of factors, which are target company countries. Target company country was formalised by generating dummy variables, one for each country.

A sufficiently large number of countries (companies belong to 86 countries in our sample) required the formalisation of a mechanism for grouping countries. Countries are deemed as belonging to the same group when they are similar in terms of their impact on the relative premium in a deal. Countries were grouped by Wald criteria. For all countries that fall into the same group, the null hypothesis about the equality of the angular coefficients is confirmed. As a result, four groups of countries were formed. There were individual countries that are not included in any of the groups. The equation for model 2 is 
$\mathrm{EVr}=\beta_{0}+\beta_{1} \ln (\mathrm{ASSETS})+\beta_{2}(\mathrm{EBIT} / \mathrm{EVm})+$ $+\beta_{3}($ REVENUE $/$ EVm $)+\sum_{\mathrm{i}=4}^{7} \beta_{\mathrm{i}}$ GrCountry $_{\mathrm{i}}+$,

$+\beta_{8}$ France $+\beta_{9}$ Portugal $+\beta_{11}$ Russia $+\beta_{12}$ USA

where GrCountry stands for the group of countries.

Regression (8) parameter estimates are presented in Table 2 (model 2).

Table 3 presents a list of countries corresponding to groups 1-4.

The explanatory power of this equation is significantly higher than for the previous equation (17.2 vs. 8.4\%), which includes only the factors of the operating and financial activities of the company. This confirms the fact that country differences in the analysis of relative premiums in mergers and acquisitions play an important role. The coefficient for group 2, which includes Oman, Zambia, and Vietnam, was not significant in model 2, model 3 and model 4 . As will be shown later, in model 5 it was possible to achieve that the angular coefficients for group 2 became significant. This can be explained by the significant difference between the sectors, which was taken into account by adding cross-variables to model 5 . The largest relative premium is characteristic, therefore, of group 3 and also of France, that is, mainly for the countries of Western and Eastern Europe. The smallest value is typical for Oman, Zambia, and Vietnam.

It seems that, perhaps, the relative premium is not determined by the country's location or the influence of macroeconomic factors only, but by variables related to the quality of the institutional environment. It is not by chance that the minimum relative premium is typical for countries with a low degree of political stability, and the maximum premium attaches to politically stable states. I suppose that testing this hypothesis is beyond the scope of this research, however, it can pose an interesting subject for further analysis.

Nevertheless, it should be recognised that the structure of clusters obtained as a result of the algorithm's operation does not correspond either to the generally accepted geographical structure of the world or to the classification of countries by level of economic development. Adding interest rates to the model made it possible not to include the time factor in the model, in particular, such events as the moment of adoption of legislation on deregulation of the electricity market.

The results of my work show that the use of existing classifications of countries (as was done, for example, in [15] by introducing a dummy variable for BRICS countries) is not sufficiently justified in analysing the premium in mergers and acquisitions. The issue of building classification for individual industries also requires further development, which was done at the next stage.

The third group of factors were included in the analysis and built model 3 . These are industries belonging to the target companies. Industries were included in the same way as countries. The dummy variables were generated for every industry. The industries grouping was carried as for countries too. The resulting regression equation is

$$
\begin{aligned}
& \mathrm{EVr}=\beta_{0}+\beta_{1} \ln (\text { ASSETS })+\beta_{2}(\text { EBIT } / \text { EVm })+ \\
& +\beta_{3}(\text { REVENUE } / \text { EVm })+\sum_{\mathrm{i}=4}^{7} \beta_{\mathrm{i}} \text { GrCountry }_{\mathrm{i}}+ \\
& +\beta_{8} \text { France }+\beta_{9} \text { Portugal }+\beta_{11} \text { Russia }+\beta_{12} \text { USA }+ \\
& +\sum_{\mathrm{i}=13}^{16} \beta_{\mathrm{i}} \text { GrIndustries }
\end{aligned}
$$

where GrIndustry ${ }_{i}$ - i-s group of industries.

Equation (9) parameter estimates are presented in Table 2 (model 3).

Table 4 presents a list of industries corresponding to

\begin{tabular}{|c|c|}
\hline Group & List of industries \\
\hline \multirow{7}{*}{$\begin{array}{l}\text { Group1 } \\
\text { (Industries) }\end{array}$} & $\begin{array}{l}\text { Bituminous Coal Underground } \\
\text { Mining }\end{array}$ \\
\hline & Commodity Contracts Dealing \\
\hline & $\begin{array}{l}\text { Data Processing, Hosting, and Related } \\
\text { Services }\end{array}$ \\
\hline & $\begin{array}{l}\text { Electric Bulk Power Transmission and } \\
\text { Control }\end{array}$ \\
\hline & Electric Power Distribution \\
\hline & $\begin{array}{l}\text { Fabricated Structural Metal } \\
\text { Manufacturing }\end{array}$ \\
\hline & Hydroelectric Power Generation \\
\hline \multirow{2}{*}{$\begin{array}{l}\text { Group } 2 \\
\text { (Industries) }\end{array}$} & Steam and Air-Conditioning Supply \\
\hline & Wind Electric Power Generation \\
\hline
\end{tabular}
groups 1-4.

Table 4. Groups of industries by the criterion of equality of relative premium

Fossil Fuel Electric Power

Generation

Geothermal Electric Power

Generation

Group 3

(Industries)

Nuclear Electric Power Generation

Other Electric Power Generation

Power and Communication Line and

Related Structures Construction

Solar Electric Power Generation

Water Supply and Irrigation Systems

$\begin{array}{ll}\text { Group 4 } & \text { Natural Gas Distribution } \\ \text { (Industries) } & \text { Sewage Treatment Facilities }\end{array}$


After the addition of the industries factor, determination increased slightly, from 17.2 to $18.7 \%$. For the industries factor, a result similar to that was expected, corresponding to a priori ideas. Group 1 includes industries related to power transmission. Group 3 includes industries related to power generation. The relative premium for industries from group 3 is higher than for industries from group 1 . At the same time, for industries from group 4, the relative premium was significantly different from zero in any of the applicable regression equation specifications (model 3, model 4, model 5).

For analysing the effect of factors, that related to market conditions, the following variables were used:

a) time interval between the moment of the announcement of the deal and the completion of the deal;

b) time interval between the moment of rumour and the completion of the deal;

c) Euribor at the time of the rumour (source [17]).

The market interest rate in the framework of the income method was applied as per L. Li and W.H.S. Tong [23]. The idea of using interest rates as a criterion for assessing the debt market is an alternative to using data on the spread of government bonds (described in the article by I.I. Rodionov and V.B. Mikhalchuk [24, p. 104]) and makes it possible to assess the world market, rather than national markets.

The corresponding regression equation is

$$
\begin{aligned}
& \mathrm{EVr}=\beta_{0}+\beta_{1} \ln (\mathrm{ASSETS})+\beta_{2}(\mathrm{EBIT} / \mathrm{EVm})+ \\
& +\beta_{3}(\mathrm{REVENUE} / \mathrm{EVm})+\sum_{\mathrm{i}=4}^{7} \beta_{\mathrm{i}} \text { GrCountry }_{\mathrm{i}}+ \\
& +\beta_{8} \text { France }+\beta_{9} \text { Portugal }+\beta_{11} \text { Russia }+\beta_{12} \mathrm{USA}+,(10) \\
& +\sum_{\mathrm{i}=13}^{16} \beta_{\mathrm{i}} \text { GrIndustries }+\beta_{17} \mathrm{COMPL}_{\mathrm{ANN}}+ \\
& +\beta_{18} \mathrm{COMPL}_{\mathrm{RUM}}+\beta_{19} \text { RUMR }
\end{aligned}
$$

where $\mathrm{COMPL}_{\mathrm{ANN}}$ represents the deal announcement time interval; $\mathrm{COMPL}_{\mathrm{RUM}}$ stands for the deal rumor time interval; and RUMR is the Euribor value at the time of the deal rumor.

Estimation results are presented in table 2 (model 4).

The addition of three variables to the model which related to market conditions allowed for an increase in the determination from 18.7 to $20.2 \%$.

The negative coefficient of the variable reflecting the time period from the moment of the announcement of the deal to the moment of completion of the deal, confirms the fact that companies are eager to complete deals which are more desirable for the initiator, and so pay a higher relative premium.

A positive coefficient for the variable reflecting the time period from the moment of rumour to the moment of completion of the deal means that a long discussion of the deal's parametersbetween the parties concerned leads to a greater likelihood of trading relative to the deal amount, which ultimately leads to a reduction in the relative premium.

A positive coefficient for the RUMR variable establishes an increase in the relative premium in a deal with an increase in the Euribor interest rate.

In fact, when financing a deal, credit funds are often used. An increase in the interest rate of Euribor leads to higher credit interest rates, so companies implement only the most profitable deals in terms of the expected effect, for which the relative premium is higher. In addition, investing in the M\&A market and in financial assets are alternative tools. It should be emphasised that the methodology of this study examines the global capital market as a comprehensive whole. The specifics of developed or developing capital markets, as well as the specifics of the capital markets of individual countries, are beyond the scope of this work.

The coefficient's estimates are stable (the signs were the same and the estimates themselves changed slightly) when new groups of factors are added. This is indirect evidence of the robustness of the estimates obtained. The sequential addition of four groups of factors while maintaining the values of the regression coefficients indirectly suggests the sustainability of those factors assessments. The coefficients values from the previous equations remain stable and do not significantly change when new factors were added.

Cross-variables were added to form the final specification of the regression model (model 5). On the basis of the original full set of cross-variables, significant factors were selected. As a result, model 5 was built. Initially, all possible cross-variables were added to build the equation, and then the ones that were only significant at the level of five percent were included. The resulting regression equation is as follows:

$$
\begin{aligned}
& \mathrm{EVr}=\beta_{0}+\beta_{1} \ln (\mathrm{ASSETS})+\beta_{2}(\mathrm{EBIT} / \mathrm{EVm})+ \\
& +\beta_{3}(\mathrm{REVENUE} / \mathrm{EVm})+\sum_{\mathrm{i}=4}^{7} \beta_{\mathrm{i}} \mathrm{GrCountry}_{\mathrm{i}}+ \\
& +\beta_{8} \text { France }+\beta_{9} \text { Portugal }+\beta_{11} \text { Russia }+\beta_{12} \mathrm{USA}+ \\
& +\sum_{\mathrm{i}=13}^{16} \beta_{\mathrm{i}} \mathrm{GrIndustries}+\beta_{17} \mathrm{COMPL}_{\mathrm{ANN}}+ \\
& +\beta_{18} \mathrm{COMPL}_{\mathrm{RUM}}+\beta_{19} \mathrm{RUMR}+ \\
& +\beta_{20} \mathrm{GrCountries}_{2}{ }^{*} \mathrm{GrIndustries}_{1}+ \\
& +\beta_{21} \text { Portugal }^{*} \mathrm{GrIndustries}_{2}+ \\
& +\beta_{22} \text { Russia }^{*} \mathrm{GrIndustries}_{2}+ \\
& +\beta_{23} \mathrm{GrCountries}_{3}{ }^{*} \mathrm{GrIndustries}_{4}+ \\
& +\beta_{24} \mathrm{USA}^{*} \text { GrIndustries }_{4} .
\end{aligned}
$$

Parameter estimates are presented in Table 5 (model 5). 
Table 5. Parameter estimates of model 5

\begin{tabular}{|c|c|c|}
\hline \multirow{2}{*}{ Variable } & \multicolumn{2}{|c|}{ Model 5} \\
\hline & $\boldsymbol{\beta}_{\mathbf{i}}$ & $\mathbf{p}_{\mathbf{i}}$ \\
\hline ASSETS_L & -2.505 & 0.000 \\
\hline EBIT/EV_M & 0.663 & 0.000 \\
\hline REVENUE/EV_M & 0.604 & 0.000 \\
\hline ACQUIRED_STAKE & -0.026 & 0.069 \\
\hline COMPL_ANN & -0.013 & 0.000 \\
\hline COMPL_RUM & 0.006 & 0.009 \\
\hline RUMR & 194.200 & 0.000 \\
\hline Group 1 (Countries) & 58.344 & 0.000 \\
\hline Group 2 (Countries) & 7.807 & 0.069 \\
\hline Group 3 (Countries) & 83.446 & 0.000 \\
\hline Group 4 (Countries) & 65.721 & 0.000 \\
\hline France & 72.402 & 0.000 \\
\hline Portugal & 45.921 & 0.000 \\
\hline Russia & 51.636 & 0.000 \\
\hline USA & 61.105 & 0.000 \\
\hline Group 1 (Industries) & -10.267 & 0.000 \\
\hline Group 2 (Industries) & -13.889 & 0.000 \\
\hline Group 3 (Industries) & -6.579 & 0.002 \\
\hline Group 4 (Industries) & 2.181 & 0.351 \\
\hline $\begin{array}{l}\text { Group } 2 \text { (Countries)* Group } 1 \\
\text { (Industries) }\end{array}$ & -9.629 & 0.071 \\
\hline Portugal ${ }^{\star}$ Group 2 (Industries) & 20.750 & 0.001 \\
\hline Russia ${ }^{\star}$ Group 2 (Industries) & 16.156 & 0.000 \\
\hline $\begin{array}{l}\text { Group } 3 \text { (Countries) }{ }^{*} \text { Group } 4 \\
\text { (Industries) }\end{array}$ & -13.190 & 0.000 \\
\hline France ${ }^{\star}$ Group 4 (Industries) & -12.000 & 0.000 \\
\hline Russia *Group 4 (Industries) & 13.683 & 0.011 \\
\hline USA * Group 4 (Industries) & -14.026 & 0.007 \\
\hline C & -63.496 & 0.000 \\
\hline R-squared & 0.210 & \\
\hline F-statistic & 66.233 & \\
\hline Prob(F-statistic) & 0.000 & \\
\hline
\end{tabular}

For the final model specification, the Variance Inflation Factors (VIF) calculation was performed, indicating that there is no highly significant multicollinearity in the model 5 (Table A1).

To assess the quality of the proposed model specification, a Ramsey test was carried out, confirming the absence of significant non-linear components that were not included in model 5 (Table A2).

Adding cross-variables improved the quality of the final regression model, which is confirmed by an increase in the coefficient of determination from 20.2 to $21.0 \%$. In addition, it should be noted that the probability value for the t-statistic and F-statistic indicators increased, which also indicates an improvement in the quality of estimation in model 5.

As a result of the inclusion of cross-variables, the influence of the countries of the second group became significant. This is unlikely to be the same for previous models, where the second group countries did not have a significant impact on the relative premium. As for the fourth group, its influence remained insignificant.

Our results can be interpreted as follows. As the size of the company's assets increases, the relative premium decreases, the ratio of the value increases EBIT to the simulated value of the business, as well as the amount of revenue to the simulated value of the business, and the relative premium increases perception of the existence of a control bonus. A one percentage point increase in the Euribor interest rate leads to a relative premium increase of about 1.94 per cent.

Countries and individual groups of countries, as well as industries, have a country premium or discount. For all groups of industries except the fourth group, the premium is statistically significant.

In addition, in our opinion, the premium of 20.75 and $16.16 \%$ respectively for companies in Portugal and Russia belonging to group 2 industries is particularly interesting. This indirectly demonstrates the high potential of knowledge-intensive and innovative industries in these countries. It is natural to have a premium of $13.68 \%$ for the branches of group 4 of Russia.

Analysis of the final model's specification confirms all the patterns obtained in previous models. In addition, it was concluded that the production and transportation of natural gas, as well as the transportation of wastewater, are industries that are characterised by a significant difference in the relative premium between countries: Russia is characterised by a positive relative premium, while for others countries the relative premium is negative. This conclusion is fully confirmed by empirical data that indicate low competition in the gas market in Russia.

\section{Conclusions and considerations}

Summing up the analysis, we come to the following conclusions. All four selected groups of factors (operational and financial activities of the target company, country of belonging for the target company, industry of belonging 
for the target company, and market conditions) are significant from the point of view of determining the relative premium in the deal.

Some of the conclusions obtained in this research fully confirm existing well-known facts. From the point of view of scientific novelty, the following conclusions are interesting:

1) The relative premium in mergers and acquisitions is a function of the value of a company's assets. For companies with large assets, on average, a lower relative premium is typical.

2) The hypothesis that companies belonging to the same geographic region (or one group of countries according to the criterion of economic development) are characterised by an equal relative premium is not confirmed.

3) Companies belonging to the electricity generation and transportation sector have different relative premiums in mergers and acquisitions, with a lower relative premium for the generation sector.

4) The time interval between the rumour about the deal, the announcement of the deal, and the completion of the deal significantly influences the relative premium.

5) The conjuncture of the debt market, namely the value of the Euribor interest rate, refers to factors that significantly affect the relative premium in deals: an increase in the Euribor value leads to an increase in the relative premium in deals.

Thus, in this article, classification of countries and industries from the standpoint of equality of relative premiums in mergers and acquisitions in the electric power industry was constructed. It was concluded that the existing classification of industries within the electric power industry is applicable from the standpoint of evaluating relative premiums in mergers and acquisitions. In addition, it was concluded that the existing country classifications cannot be applicable from the perspective of evaluating relative premiums in mergers and acquisitions; therefore, a new country classification was proposed.

Further development of this model may include the creation of a new classification of countries applicable to the analysis of mergers and acquisitions.

\section{References}

1. Ahammad M.F., Tarba S.Y., Liu Y., Glaister K.W. Knowledge transfer and cross-border acquisition performance: The impact of cultural distance and employee retention. International Business Review. 2016;25(1, Pt. A):66-75. DOI: 10.1016/j. ibusrev.2014.06.015

2. Alexandridis G., Fuller K.P., Terhaar L., Travlos N.G. Deal size, acquisition premia and shareholder gains. Journal of Corporate Finance. 2013;20:1-13. DOI: 10.1016/j.jcorpfin.2012.10.006
3. Bertrand O., Betschinger M.-A. Performance of domestic and cross-border acquisitions: Empirical evidence from Russian acquirers. Journal of Comparative Economics. 2012;40(3):413-437. DOI: 10.1016/j.jce.2011.11.003

4. Humphery-Jenner M., Powell R. Firm size, sovereign governance, and value creation: Evidence from the acquirer size effect. Journal of Corporate Finance. 2014;26:57-77. DOI: 10.1016/j.jcorpfin.2014.02.009

5. Kishimoto J., Goto M., Inoue K. Do acquisitions by electric utility companies create value? Evidence from deregulated markets. Energy Policy. 2017;105: 212224. DOI: 10.1016/j.enpol.2017.02.032

6. Lim M.-H., Lee J.-H. The effects of industry relatedness and takeover motives on cross-border acquisition completion. Journal of Business Research. 2016;69(11):4787-4792. DOI: 10.1016/j. jbusres.2016.04.031

7. Barbopoulos L.G., Adra S. The earnout structure matters: Takeover premia and acquirer gains in earnout financed M\&As. International Review of Financial Analysis. 2016;45:283-294. DOI: 10.1016/j. irfa.2016.04.007

8. Ahern K.R., Daminelli D., Fracassi C. Lost in translation? The effect of cultural values on mergers around the world. Journal of Financial Economics. 2015;117(1):165-189. DOI: 10.1016/j. jifineco.2012.08.006

9. Erel I., Liao R.C., Weisbach M.S. Determinants of cross-border mergers and acquisitions. The Journal of Finance. 2012;67(3):1045-1082. DOI: 10.1111/j.15406261.2012.01741.x

10. Bauer F., Matzler K. Antecedents of M\&A success: The role of strategic complementarity, cultural fit, and degree and speed of integration. Strategic Management Journal. 2014;35(2):269-291. DOI: 10.1002/smj.2091

11. Boateng A., Hua X., Uddin M., Du M. Home country macroeconomic factors on outward cross-border mergers and acquisitions: Evidence from the UK. Research in International Business and Finance. 2014;30:202-216. DOI: 10.1016/j.ribaf.2013.08.001

12. Bonaime A., Gulen H., Ion M. Does policy uncertainty affect mergers and acquisitions? Journal of Financial Economics. 2018;129(3):531-558. DOI: 10.1016/j.jfineco.2018.05.007

13. Col B., Errunza V. Corporate governance and state expropriation risk. Journal of Corporate Finance. 2015;33:71-84. DOI: 10.1016/j.jcorpfin.2015.04.005

14. Cai Y., Tian X., Xia H. Location, proximity, and M\&A transactions. Journal of Economics \& Management Strategy. 2016;25(3):688-719. DOI: 10.1111/ jems.12159 
15. Балашов А.И., Подцикина С.В. Оценка влияния финансовых параметров на стоимость сделок слияния и поглощения фармацевтических компаний. Экономический анализ: теория и практика. 2015;(22):15-26.

16. Balashov A.I., Podtsikina S.V. Assessing the impact of financial parameters on the mergers and acquisitions value of pharmaceutical companies. Ekonomicheskii analiz: teoriya i praktika = Economic Analysis: Theory and Practice. 2015;(22):15-26. (In Russ.).

17. Лузина Д.С., Рогова Е.М. Оценка влияния сделок слияний и поглощений на фундаментальную стоимость компаний в странах БРИКС. Корпоративные финансы. 2015;9(3):27-50. DOI: 10.17323/j. jcfr.2073-0438.9.3.2015.27-50

18. Luzina D.S., Rogova E.M. The effect of mergers and acquisitions on companies' fundamental values at BRICS countries. Korporativnye finansy = Journal of Corporate Finance Research. 2015;9(3):27-50. (In Russ.). DOI: 10.17323/j.jcfr.2073-0438.9.3.2015.27-50

19. Euribor Rates. URL: https://www.euribor-rates.eu/

20. Скворцова И.В., Красовицкий А.Д. Особенности сделок слияний и поглощений инновационных компаний на развитых и развивающихся рынках капитала. Корпоративные финансы. 2018;12(4):8698. DOI: 10.17323/j.jcfr.2073-0438.12.4.2018.86-98

21. Skvortsova I.V., Krasovitskii A.D. Mergers and acquisitions of innovative companies in developed and emerging capital markets: What sets them apart? Korporativnye finansy = Journal of Corporate Finance Research. 2018;12(4):86-98. (In Russ.). DOI: 10.17323/j.jcfr.2073-0438.12.4.2018.86-98

22. Aharon D.Y., Gavious I., Yosef R. Stock market bubble effects on mergers and acquisitions. The Quarterly Review of Economics and Finance. 2010;50(4):456-470. DOI: 10.1016/j.qref.2010.05.002
23. Li J., Li P., Wang B. Do cross-border acquisitions create value? Evidence from overseas acquisitions by Chinese firms. International Business Review. 2016;25(2):471-483. DOI: 10.1016/j. ibusrev.2015.08.003

24. Ma Q., Whidbee D.A., Zhang A.W. Value, valuation, and the long-run performance of merged firms. Journal of Corporate Finance. 2011;17(1):1-17. DOI: 10.1016/j.jcorpfin.2010.07.001

25. Масленникова М.В., Партин И.М. Детерминанты эффективности международных сделок по приобретению компаний из стран Европейского союза. Корпоративные финансы. 2015;9(3):63-81. DOI: 10.17323/j.jcfr.2073-0438.9.3.2015.63-81

26. Maslennikova M.V., Partin I.M. Determinants of M\&A effectiveness in acquisitions of EU companies. Korporativnye finansy = Journal of Corporate Finance Research. 2015;9(3):63-81. (In Russ.). DOI: 10.17323/j.jcfr.2073-0438.9.3.2015.63-81

27. Li L., Tong W.H.S. Information uncertainty and target valuation in mergers and acquisitions. Journal of Empirical Finance. 2018;45:84-107. DOI: 10.1016/j. jempfin.2017.09.009

28. Родионов И.И., Михальчук В.Б. Обзор основных теоретических подходов и эмпирических исследований эффективности сделок слияний и поглощений. Корпоративные финансы. 2015;9(3):98-110. DOI: 10.17323/j.jcfr.2073-0438.9.3.2015.98-110

29. Rodionov I.I., Mikhal'chuk V.B. Review of major theoretical and empirical studies on M\&A synergy. Korporativnye finansy = Journal of Corporate Finance Research. 2015;9(3):98-110. (In Russ.). DOI: 10.17323/j.jcfr.2073-0438.9.3.2015.98-110 


\section{Appendices}

Table A1. VIF model 5

\begin{tabular}{|c|c|}
\hline Variable & VIF \\
\hline ASSETS_L & 1.701 \\
\hline EBIT/EV_M & 3.255 \\
\hline REVENUE/EV_M & 3.408 \\
\hline ACQUIRED_STAKE & 1.554 \\
\hline COMPL_ANN & 4.204 \\
\hline COMPL_RUM & 4.374 \\
\hline RUMR & 1.225 \\
\hline Group 1 (Countries) & 35.878 \\
\hline Group 2 (Countries) & 3.645 \\
\hline Group 3 (Countries) & 23.003 \\
\hline Group 4 (Countries) & 34.473 \\
\hline France & 19.490 \\
\hline Portugal & 10.790 \\
\hline Russia & 13.283 \\
\hline USA & 4.812 \\
\hline Group 1 (Industries) & 10.935 \\
\hline Group 2 (Industries) & 3.539 \\
\hline Group 3 (Industries) & 11.021 \\
\hline Group 4 (Industries) & 7.074 \\
\hline Group 2 (Countries) ${ }^{*}$ Group 1 (Industries) & 2.788 \\
\hline Portugal ${ }^{*}$ Group 2 (Industries) & 1.133 \\
\hline Russia ${ }^{*}$ Group 2 (Industries) & 1.363 \\
\hline Group 3 (Countries) ${ }^{*}$ Group 4 (Industries) & 1.505 \\
\hline France ${ }^{*}$ Group 4 (Industries) & 2.219 \\
\hline Russia ${ }^{*}$ Group 4 (Industries) & 1.141 \\
\hline USA ${ }^{*}$ Group 4 (Industries) & 1.386 \\
\hline $\mathrm{C}$ & \\
\hline
\end{tabular}

Table A2. Ramsey test for model 5

\begin{tabular}{cccc} 
Variable & Value & df & Probability \\
t-statistic & 1.280 & 6476.000 & 0.201 \\
\hdashline F-statistic & 1.639 & $(1,6476)$ & 0.201 \\
\hdashline Likelihood ratio & 1.646 & 1.000 & 0.200
\end{tabular}

